Canadian Science Publishing

Canadian Journal of Earth Sciences Revue canadienne des sciences de la Terre

\title{
Holocene glacier history of Frank Mackie Glacier, northern British Columbia Coast Mountains
}

\begin{tabular}{|r|l|}
\hline Journal: & Canadian Journal of Earth Sciences \\
\hline Manuscript ID & cjes-2015-0236.R2 \\
\hline Manuscript Type: & Article \\
\hline Date Submitted by the Author: & 10 -Aug-2016 \\
\hline Keyword: List of Authors: & $\begin{array}{l}\text { St-Hilaire, Vikki; University of Victoria, University of Victoria Tree-Ring } \\
\text { Laboratory, Department of Geography } \\
\text { Smith, Dan; University of Victoria Tree-Ring Laboratory }\end{array}$ \\
\hline & $\begin{array}{l}\text { Ranges } \\
\text { Raciology, Holocene, glacier history, British Columbia, Boundary }\end{array}$ \\
\hline
\end{tabular}




\title{
Holocene glacier history of Frank Mackie Glacier, northern British Columbia Coast Mountains
}

\author{
Vikki M. St-Hilaire and Dan J. Smith \\ University of Victoria Tree-Ring Laboratory \\ Department of Geography \\ University of Victoria \\ Victoria, British Columbia V8W 3R4 \\ Canada.
}

Corresponding author: D.J. Smith, e-mail: smith@uvic.ca, phone: (250) 721-7328 


\begin{abstract}
Frank Mackie Glacier repeatedly advanced across the Bowser River valley in northwestern British Columbia to impound Tide Lake during the Holocene. The most recent infilling of Tide Lake was associated with a late Little Ice Age glacier advance and ended around 1930 when the lake catastrophically drained. Over the last century Frank Mackie Glacier has retreated and down wasted to reveal multiple glaciogenic sedimentary units within the proximal faces of prominent lateral moraines. The units are separated by buried in-situ tree stumps and laterally contiguous wood mats deposited on paleosols. Dendroglaciological and radiocarbon dating of these wood remains show that Frank Mackie Glacier expanded into standing forests at 3710-3300, 2700-2200, 1700-1290, 900-500, and 250-100 cal. yr BP. These advances coincide closely in time with the previously established Tide Lake glacier dam chronology and with the Holocene history of other glaciers in the Bowser River watershed. The findings emphasize the likelihood that most glaciers within northwestern British Columbia underwent substantial size and mass balance changes over the last 4000 years, and often spent hundreds of years in advanced positions before retreating.
\end{abstract}

Keywords: dendroglaciology and tree-rings, Holocene, glacier history, British Columbia, Boundary Ranges 


\section{Introduction}

Glaciers worldwide have been retreating following the end of the Little Ice Age (LIA) in approximately 1850 A.D. (Dyurgerov and Meier 2000; Dyurgerov and Mccabe 2006). As the pace of this glacier recession and down wasting has increased over the last fifty years (Chapin et al. 2013), valley-side slopes and lateral moraines in many regions are collapsing leading to deformation, rock avalanches, debris flows and slides (Holm et al. 2004). At many sites these slope failures are exposing previously unseen glaciogenic sedimentary units separated by paleosols and the subfossil remains of trees buried during earlier glacier activity. Overwhelmed and killed during discrete glacial advances, the tree remains can be dated using dendrochronological methodologies and/or radiometric techniques (Coulthard and Smith 2013) to provide singular records of the long-term mass balance response to changing climates (Winkler and Matthews 2010).

Recent research focused on glaciers located within the Coast Mountains of northwestern British Columbia (B.C.) draws attention to the limitations in our knowledge of their Holocene behaviour (Menounos et al. 2009; Mood and Smith 2015), especially when compared to the outcome of research within nearby Alaska and the southern Coast Mountain regions (Solomina et al., 2015; 2016). A regional exception is the developing understanding of Holocene glacier behaviour within the Bowser River watershed and adjacent Cambria Icefield area in northwestern B.C. Following on the pioneering work of Clague and Mathewes (1992) and Mathews and Clague (1993) at Tide Lake and Berendon Glacier, a number of researchers have described multiple advance and retreat intervals from the mid-Holocene through to the LIA in this region (Jackson et al. 2008; Harvey et al. 2012; Johnson and Smith 2012; Osborn et al. 2012; Hoffman and Smith 2013). 
In this paper we focus attention on Frank Mackie Glacier where lowering of the ice surface within the last few decades has uncovered the proximal face of prominent lateral moraines alongside the glacier and within the adjacent Bowser River Valley. Only recently exposed, these vertical exposures reveal that the moraines are composed of multiple glaciogenic sedimentary units separated by laterally contiguous wood mats, buried in-situ tree stumps and paleosols. We use ages assigned to the wood samples to describe the Holocene activity of Frank Mackie Glacier, and to advance understanding of the Holocene behaviour of glaciers within the Bowser River watershed and northern Coast Mountains. The study provides greater temporal resolution for Holocene glacier advances in the region and constrains the timing and of duration of these advances.

\section{Study Area}

Frank Mackie Glacier is located within the headwaters of the Bowser River watershed in northwestern B.C., approximately $50 \mathrm{~km}$ north of Stewart, B.C. and Hyder, Alaska (Fig. 1). Above Bowser Lake, the mountainous headwaters of the watershed straddling the international border with Alaska are characterized by icefields feeding into large valley glaciers including Salmon, Berendon, Frank Mackie, Canoe, Knipple and Charlie glaciers in B.C. (Fig. 1). To the east, Todd Glacier and several smaller glaciers drain from the Todd Icefield into northwardflowing Todd Creek, a tributary of the Bowser River that enters the valley $5 \mathrm{~km}$ above Bowser Lake.

The Bowser River watershed is located within the Boundary Range ecoregion (B.C. Ministry of Environment 2013), with the dominant forest cover consisting of mixed stands of subalpine fir (Abies lasiocarpa) and mountain hemlock (Tsuga mertensiana) trees. At Stewart, 
the annual air temperature averages $6{ }^{\circ} \mathrm{C}$ and the annual total precipitation exceeds $1840 \mathrm{~mm} / \mathrm{yr}$, with more than 30\% falling as snow (Environment Canada 2014).

Frank Mackie Glacier extends $10 \mathrm{~km}$ down valley from its source at ca. $1400 \mathrm{~m}$ asl in the Frank Mackie Icefield to terminate at ca. $600 \mathrm{~m}$ asl in 2013 (56 20'28'N, 13005'16”; Fig. 1). Similar to other glaciers in northwestern B.C. and nearby Alaska (Mood and Smith 2015; Schiefer et al. 2008; Solomina et al. 2015; 2016), Frank Mackie Glacier has retreated and down wasted significantly over the past century (Fig. 2; Table 1). Aerial photographs show that the glacier terminus extended across the Bowser River valley in 1972, but by 2009 the glacier had retreated up valley and was largely constrained to its tributary valley (Figs. 2 and 3).

During the Holocene, Frank Mackie Glacier extended across the Bowser River Valley, damming the river to impound Tide Lake between Frank Mackie and Berendon glaciers (Haumann 1960). At its maximum length of $8.5 \mathrm{~km}$ and width of $1.7 \mathrm{~km}$, the lake impounded over $1 \mathrm{~km}^{3}$ of water (Clague and Mathews 1992). Stratigraphic and radiocarbon evidence demonstrate that the glacier dam failed multiple times during the Holocene (Hanson 1932; Clague and Mathewes 1996), producing outburst floods whose effects are recorded $28 \mathrm{~km}$ downstream in Bowser Lake (Gilbert et al. 1997). The last phase of Tide Lake was associated with a $17^{\text {th }}$ century LIA advance of Frank Mackie Glacier and ended following incision of a kame moraine that impounded the lake until approximately 1930 A.D. (Clague and Mathews 1992; Clague and Mathewes 1996). Examination of sediments exposed following drainage of the lake indicate that Frank Mackie Glacier advanced into the Bowser River Valley at least four times during the Holocene (Hanson 1932; Clague and Mathews 1992).

Prior descriptions of the Holocene behaviour of glaciers in the Boundary Ranges result from field studies at outlet glaciers flowing from the Frank Mackie, Todd, Cambria and Andrei 
icefields (Hoffman and Smith 2013; Jackson et al. 2008; Mood and Smith 2015). Based on stratigraphic analyses of exposed sediments and drill cores analyses, Clague and Mathews (1992) and Clague and Mathewes (1996) describe advances of Berendon and Frank Mackie glaciers prior to 3000 cal. yr BP, in ca. $2940-2540,1570-1300$, and in 1050-770 cal. yr BP $(2700 \pm 60$, $1520 \pm 50$, and $990 \pm 60{ }^{14} \mathrm{C}$ yr BP). The peak LIA advance occurred at ca. 350 cal. yr BP (1600 A.D.) and ended at 50 cal. yr BP (1900 A.D.) (Clague and Mathews 1992).

Jackson et al. (2008) report that glaciers flowing from the Todd Icefield advanced prior to 3400 cal. yr BP, in ca. $3340-2930,2490-2150$, and $1550-1270$ cal. yr BP $(2960 \pm 70,2300 \pm 60$, in $1440 \pm 60{ }^{14} \mathrm{C}$ yr BP), and during three phases of LIA expansion beginning in $780-560 \mathrm{cal}$. yr BP (730 $\pm 60{ }^{14} \mathrm{C}$ yr BP). Harvey et al. (2012) indicate that Canoe Glacier expanded into the Bowser River valley in $5450-5050$ and $3710-3460$ cal. yr BP $\left(4570 \pm 50\right.$ and $3360 \pm 50{ }^{14} \mathrm{C}$ yr BP).

Outlet glaciers from the nearby Cambria Icefield (30 km south-east of Frank Mackie Glacier; Fig. 1) advanced down valley during several discrete intervals since the mid-Holocene. The snout of Bear River Glacier advanced into standing trees at least three times from 4220 to 3390 cal. yr BP $\left(3680 \pm 60-3310 \pm 70{ }^{14} \mathrm{C}\right.$ yr BP $)$ and at least once in $1060-800$ cal. yr BP $\left(1040 \pm 50{ }^{14} \mathrm{C}\right.$ yr BP) (Jackson et al. 2008; Osborn et al. 2012). Eastward flowing South Flat and White glaciers advanced down valley in $1530-1200$ cal. yr. BP $\left(1550 \pm 50-1280 \pm 50{ }^{14} \mathrm{C}\right.$ yr BP $)$ and again during $950-540$ cal. yr. BP $\left(960 \pm 40-610 \pm 60{ }^{14} \mathrm{C}\right.$ yr BP) (Johnson and Smith 2012). At Bromley Glacier thick wood mats within a prominent lateral moraine show that the glacier thickened and overwhelmed standing trees in 2700-2400, 1870-1710, 1390-1300, and 790-690 cal. yr BP $\left(2720 \pm 30,1850 \pm 30-1480 \pm 30\right.$ and $830 \pm 30{ }^{14} \mathrm{C}$ yr BP) (Hoffman and Smith 2013).

\section{Methods}


Field surveys of recently exposed proximal moraine faces were undertaken where Frank Mackie Glacier flows into the Bowser River trunk valley (Fig. 3). Where subfossil wood remains were encountered within the units, representative samples with bark or intact perimeter wood were collected with a chainsaw for dendroglaciological and radiocarbon dating. Increment cores were collected from living trees found growing above the Holocene glacial limit to facilitate treering cross-dating (Coulthard and Smith 2013).

The wood samples were allowed to air dry at the University of Victoria Tree-Ring Laboratory (UVTRL), after which species identification was completed using a $40 \times$ microscope and a reference key (Hoadley 1990). Following standardized preparation procedures (Stokes and Smiley 1968), the width of each annual tree ring in the core and subfossil samples was measured along two paths from pith to perimeter using WinDENDRO (ver. 2012). Individual ring-width series were visually cross-dated and verified using COFECHA (Grissino-Mayer 2001), with the living series combined to construct cross-dated tree-ring chronologies using ARSTAN (Ver41d) (Cook and Krusic 2005). Series correlations (Pearson correlation coefficient, r) for chronologies, significant at the $99 \%$ confidence level, were calculated with COFECHA for 50 year segments with 25 year overlaps. Series correlation values greater than 0.3281 were accepted as providing statistically significant cross-dates (Holmes, 1983).

Floating (undated) tree-ring chronologies were constructed by cross-dating the subfossil wood, after which an attempt was made to assign an absolute age by cross-dating to living chronologies (Coulthard and Smith 2013). Where cross-dating failed, representative perimeter wood samples from the floating chronologies were radiocarbon dated by Beta Analytic Inc. and the ages provided were used to assign relative calendar ages to the floating chronologies. The radiocarbon ages were converted to calendar years using the INTCAL13 calibration curve 
(Reimer et al. 2013) which accounts for temporal fluctuations in the atmospheric ${ }^{14} \mathrm{C} /{ }^{12} \mathrm{C}$ ratio (Walker 2005). The calibrated ages were calculated to 2-sigma standard deviation.

Magnitude and timing of glacier advances were discerned from the stratigraphic position and age of the subfossil tree remains (Ryder and Thomson 1986). In-situ samples were assumed to provide a maximum-age for a glacier advance, whereas detrital samples with unknown provenance were used only in the construction of the floating chronologies. For this study, we considered in-situ subfossil wood samples to include samples found in growth position (i.e. rooted stumps) and large intact boles with bark found within or pressed into a paleosol (Mood and Smith 2015). As all the sites examined were remote from snow avalanche slopes, we presume the boles to be the remains of glacially-killed trees transported only a short distance from where they were rooted (i.e. Le Roy et al. 2009).

\section{Observations}

\section{Living tree-ring chronologies}

Increment cores were collected from a mixed stand of 200-300 year old mountain hemlock and subalpine fir trees found growing on an open rocky slope positioned above the LIA trim line at $835 \mathrm{~m}$ asl (56 $19^{\prime} 19^{\prime \prime} \mathrm{N}, 130^{\circ} 5^{\prime} 57^{\prime \prime} \mathrm{W}$; Site 4 in Fig. 3). Rotted and only weakly crossdated $(r<0.400)$, the chronologies constructed from these trees were unsuited for cross-dating the floating chronologies. Instead, we used mountain hemlock (1599 to 2004 A.D.) and subalpine fir (1649 to 2004 A.D.) chronologies constructed from trees found in the Todd Icefield area $\left(56^{\circ} 12^{\prime} 21^{\prime \prime} \mathrm{N}, 129^{\circ} 35^{\prime} 13^{\prime \prime} \mathrm{W} ; 955 \mathrm{~m}\right.$ asl). Both chronologies are characterized by robust treering statistics, indicating they are well-suited for cross-dating (Jackson et al. 2008).

\section{Site Descriptions}

Site 1- Lower moraine 
Site 1 consists of a large, bowl-shaped gully set into the proximal face of lateral moraine deposits in the Bowser River valley (56 $19^{\prime} 31^{\prime \prime N}, 130^{\circ} 5^{\prime} 37^{\prime \prime} \mathrm{W}$; Figs. 4 and 5). The site is located ca. $850 \mathrm{~m}$ south of the glacier. A transect established vertically up the gully, from 700 to $725 \mathrm{~m}$ asl, revealed that the moraine is composed of several lithostratigraphic units separated by prominent woody layers (WL) (Fig. 6). The lower portion of the section was comprised of an 8 $\mathrm{m}$ thick unit of diamict (unit 1) extending below $700 \mathrm{~m}$ asl. Units 1, 5 and 7 were composed of diamict, units 2 and 4 of sand, units 3, 4 and 6 consisted of clay to silt sized sediments, and the upper unit was comprised of mainly gravels (Fig. 6).

A woody layer (WL1) at $700 \mathrm{~m}$ asl within the diamict unit, consists of a black, undulating organic horizon containing numerous in-situ boles (Fig. 6), including FM05-0103 which yielded a radiocarbon age of $1760 \pm 40{ }^{14} \mathrm{C}$ years BP $(1810-1570$ cal. yr BP, Table 2). Above WL1 at $705 \mathrm{~m}$ asl, three upright boles in growth position were located adjacent to the gully wall. FM0501-04 dated to $870 \pm 40{ }^{14} \mathrm{C}$ years BP (910-700 cal. yr BP) (Table 2).

A second wood mat (WL2) horizontally transects the gully at $715 \mathrm{~m}$ asl (Fig. 6).

Overlying clay-silt sized sediments and positioned below a sandy unit, detrital wood samples were collected immediately below and above WL2 for cross-dating purposes. A bole (FM050110) collected from within WL2 dates to $860 \pm 40{ }^{14} \mathrm{C}$ years BP (910-690 cal. yr BP, Table 2). A third wood mat (WL3) was found at $720 \mathrm{~m}$ asl, close to the upper extent of the gully. Three in-situ boles were collected for cross-dating directly above a clay-silt unit and below a diamict unit (Fig. 6). FM0501-06 yielded a radiocarbon age of $560 \pm 50{ }^{14} \mathrm{C}$ years BP $(650-510$ cal. yr BP, Table 2).

Site 2 - Upper moraine: 
Three nested moraine crests at ca. $835 \mathrm{~m}$ asl were identified at Site $2\left(56^{\circ} 19^{\prime} 16^{\prime \prime} \mathrm{N}\right.$, $130^{\circ} 5^{\prime} 43^{\prime \prime}$; Figs. 3 and 7). A gully eroded through the most proximal moraine shows that it is primarily composed of a massive diamict with a woody layer (WL4) buried within reddish claysized sediments. Nine in-situ and four detrital samples were collected between 808 and $818 \mathrm{~m}$ asl for cross-dating (Table 3).

Site 3 - Moraine complex/ spill area

Thirty-eight detrital samples were collected (580 to $700 \mathrm{~m}$ asl) below the proximal lateral moraine face at Site $3\left(56^{\circ} 19^{\prime} 38^{\prime \prime} \mathrm{N}, 130^{\circ} 5^{\prime} 30^{\prime \prime} \mathrm{W}\right.$; Fig 3). Included were samples from a small post-glacial landslide, as well as samples contained within debris flow and fluvial deposits transported out of the gully at Site 1.

\section{Site 5 - North lateral moraine}

Site 5 is located within lateral moraine deposits along the north side of the glacier terminus at $755-757 \mathrm{~m}$ asl $\left(56^{\circ} 20^{\prime} 53^{\prime \prime} \mathrm{N}, 130^{\circ} 05^{\prime} 38^{\prime \prime} \mathrm{W}\right.$; Figs. 3 and 8$)$. Exposed within the walls of a prominent gully at Site 5 was an organic mat $(\sim 10 \mathrm{~cm})$ with identifiable fir needles and an underlying paleosol buried beneath a thick $(>20 \mathrm{~m})$ diamict deposit. Numerous broken boles, oriented down valley, rest on the surface of the organic mat (WL5). One in-situ bole (FM05-24) was killed in $2490 \pm 40{ }^{14} \mathrm{C}$ years BP (2740-2380 cal. yr BP) and a second (FM05-23) in $2380 \pm$ $40{ }^{14}$ C years BP (2690-2330 cal. yr BP) (Table 2).

Site 6 - Spill area below north lateral moraine

Site 6 consists of a large gully incised through the north lateral moraine $\left(56^{\circ} 20^{\prime} 53^{\prime \prime} \mathrm{N}\right.$, $130^{\circ} 05^{\prime} 38^{\prime \prime}$; Fig. 3). Over 50 detrital samples were collected from within the outwash zone of this gully at 685 to $670 \mathrm{~m}$ asl for cross-dating.

\section{Dendrochronological Results}


In total, 95 subfossil wood samples were collected for analysis. Approximately one third of the samples were discarded as they could not be internally cross-dated due to the presence of reaction wood, rot and other growth anomalies, or they contained too few rings $(<50)$ for robust cross-dating to a master chronology. This preliminary assessment left 57 samples with internal cross-dating correlations of $r \geq 0.400$ available for constructing floating chronologies. Five additional samples, including two radiocarbon dated samples collected during field surveys at nearby Canoe (Harvey and Smith 2012) and Charlie glaciers (St-Hilaire 2014) were also available and were included in the cross-dating analyses (Table 3).

A total of six floating chronologies were constructed from 44 samples (Table 3). Four floating chronologies (Chron. A, B, C, and D), with interseries correlations values ranging from 0.443 to 0.457 , were successfully cross-dated to radiocarbon-dated samples (Fig. 9). Two floating chronologies (Chron. E and F) cross-date to the living chronologies collected by Jackson et al. (2008) in the Todd Icefield area (Fig. 9). To allow for comparison with the absolute dates assigned to Chron. E and F, the relative ages assigned to Chron. A-D were anchored to the mean of the calibrated radiocarbon ages (Table 2). In Fig. 9, error bars are presented to illustrate the potential age range of each sample.

\section{Stratigraphic Interpretation}

Recent recession, downwasting and valley-side slumping at Frank Mackie Glacier has exposed the proximal faces of lateral moraines both within the Bowser River valley and the glacier's tributary valley. The stratigraphy of the lower southern lateral moraine (Site 1) indicates that these moraines are composite features originating from fluctuating energy and geomorphic regimes during the late Holocene, as demonstrated by alternating moraine, fluvial and lacustrine sediment units (Figs. 4 and 6). As Frank Mackie Glacier advanced in $1760 \pm 40{ }^{14} \mathrm{C}$ years BP 
(1810-1570 cal) it overrode and buried a standing valley-side forest (WL1) beneath diamict (Unit 1) at Site 1. During a succeeding interval of glacier recession, fluvial sediments consisting of a well-sorted unit of sands were (Unit 2) deposited in an ice marginal stream. The sands grade upward and interfinger into the lowest part of several metres of laminated clay-silt sized sediments (Unit 3) that presumably accumulated within an ice marginal lake or pond. Following drainage of the lake and an interval of at least 187 years, Frank Mackie Glacier advanced toward this location to deposit glaciofluvial sands (Unit 4) that buried and killed the trees at WL2 by 860 $\pm 40{ }^{14} \mathrm{C}$ years BP (910-690 cal. yr BP, Table 2). The sand unit is capped by a diamict (Unit 5) deposited as the glacier advanced over Site 1. Following this early LIA advance the glacier retreated from the site, allowing for the formation of an ice marginal pond into which clay-silt sized sediment accumulated (Unit 6). Following drainage of the pond and establishment of a trees that grew for at least 150 years (WL3), Frank Mackie Glacier advanced across Site 1 in the late LIA to bury the remains of this forest beneath a diamict (Unit 7). The advance occurred by ca. 230-130 cal. yr BP (1720-1820 A.D.) (Table 3), when the glacier had thickened $110 \mathrm{~m}$ upwards to the LIA lateral moraine crests identified at the upper extent of the diamict sediments at Site 2 (Fig. 5). It is likely that maximum Holocene ice levels persisted at this elevation until the end of $19^{\text {th }}$ century, given the persistent lack of vegetation and tree re-colonization below the trim line ( $835 \mathrm{~m}$ asl) at sites 1 and 2 .

\section{Discussion and Regional Synthesis}

Our investigations at Frank Mackie Glacier allow for identification of five discrete glacial advances after 4000 cal. yr BP (Fig. 10). We did not find any evidence of early Holocene glacier activity, such as the episodes reported at Sphaler Glacier $100 \mathrm{~km}$ to the northwest in the Andrei Icefield area at 8998-8699 and 7937-7694 cal. yr BP (Mood and Smith 2015) which coincide 
with the global $8.2 \mathrm{ka}$ event (Kobashi et al. 2007). Nor did we locate evidence for glacier expansion at 5202-5047 or 4100-4020 cal. yr BP, as found at Canoe and Bear River glaciers, respectively (Harvey et al. 2012; Osborn et al. 2013). If these early and mid-Holocene events occurred at Frank Mackie Glacier, evidence of them has either been obscured by later late Holocene glacier activity or it remains to be discovered.

The earliest record of glacier expansion at Frank Mackie Glacier comes from Tide Lake sediments. Clague and Mathews (1992) describe sedimentary evidence in exposed bluffs and from a drill core taken in the southern section of the Tide Lake basin. Interpreted as resulting from damming of the Bowser River prior to 3000 cal. yr BP, this advance likely occurred around 3710-3460 cal. yr BP when nearby Canoe Glacier expanded into the Bowser River Valley (Harvey et al. 2012). Detrital wood samples from Site 6 cross-date to the radiocarbon dated Canoe Glacier samples, possibly indicating that Frank Mackie Glacier was also advancing and killing valley-side trees during this interval (Fig. 10, Table 3).

A second advance of Frank Mackie Glacier was underway from 2700-2200 cal. yr BP, when a standing forest on the northern lateral moraine at sites 5 and 6 was buried during the deposition of lateral moraine sediments. This advance corresponds to sedimentary records from Tide Lake (Clague and Mathews 1992; Fig. 10), as well as to contemporaneous advances of valley glaciers flowing from the Todd and Cambria icefields (Jackson et al. 2008; Hoffman and Smith 2013; Osborn et al. 2013).

Following the 2700-2200 cal. yr BP advance, Frank Mackie Glacier retreated up valley before readvancing at 1900-1500 cal. yr BP to bury trees colonizing moraine sediments at sites 1 and 3 of the southern lateral moraine (Figs. 9 and 10). Corresponding glacier advances in the Todd Icefield area (Jackson et al. 2008), as well as in the Andrei and nearby Cambria icefield 
areas (Johnson and Smith 2012; Hoffman and Smith 2013; Mood and Smith 2015), attest to the regional significance of this first millennium A.D. event (Reyes et al. 2006). Sedimentation and lack of disturbance of detrital wood and conifer needles recovered from Tide Lake sediments, dating from 1700-1290 cal. yr BP, suggest Frank Mackie Glacier remained in an advanced position for several hundred years following this advance (Clague and Mathews 1992).

By 900-500 cal. yr BP, Frank Mackie Glacier was advancing down valley and expanding up the surrounding valley walls during an early LIA glacial event (Figs. 9 and 10), at the same time as Bear River, Bromley, South Flat, Todd, and White glaciers in the Cambria Icefield were also advancing into standing forests (Jackson et al. 2008; Johnson and Smith 2012; Hoffman and Smith 2013; Osborn et al. 2013). This advance appears to have been more extensive than any other within the previous 2000 years, with in-situ stumps at Frank Mackie Glacier (Site 2) found buried beneath moraine sediments over $100 \mathrm{~m}$ above the upper limit of sediments deposited during earlier Holocene advances.

Following a brief hiatus that likely included a short-lived interval of terminus retreat and ice surface lowering, as seen by evidence of renewed tree growth (Table 3), Frank Mackie Glacier expanded in 250-100 cal. yr BP to kill and bury a valley-side stand of trees at Site 2 (Figs. 3 and 5). This late LIA advance occurred at the same time as glaciers flowing from the Todd Icefield were killing and burying mature trees (Jackson et al. 2008). Dendroglaciological evidence demonstrates that the magnitude of this late LIA advance was similar to the early LIA advance, with logs buried immediately below the trim line at Site 2 . This advance coincides with the Holocene glacier maximum and is recorded across the Coast Mountains (Desloges and Ryder 1990; Menounos et al. 2009; Mood and Smith 2015).

\section{Conclusions}


Dendroglaciological and radiocarbon dating of wood remains buried by repeated advances of Frank Mackie Glacier confirm and reinforce prior interpretations of its late Holocene glacier activity. Intervals of glacier expansion at 3710-3300, 2700-2200, 1700-1290, 900-500, and 250-100 cal. yr BP coincide closely in time with the Tide Lake glacier dam chronology established by Clague and Mathews (1992). Taken together, the two records indicate that following each of the five late Holocene expansion events, Frank Mackie Glacier remained in an advanced position, for hundreds of years in some instances, to dam the Bowser River.

The late Holocene history of Frank Mackie Glacier closely matches that established for of other glaciers in northwestern B.C. (Menounos et al. 2009; Mood and Smith 2015). It emphasizes these glaciers underwent substantial size and mass balance changes over the last 4000 years, often times spending hundreds of years in advanced positions. Given the rapid response of Frank Mackie Glacier to climate changes over the last century (Table 1), additional research on early to mid-Holocene lateral moraine stratigraphy and dendroglaciology is warranted to fully appreciate the glaciological changes certain to accompany the climate changes projected to occur in northwestern B.C. over the next century.

\section{Acknowledgements}

Funding for this study was provided by grants from the National Sciences and Engineering Research Council of Canada (NSERC) and the Canadian Foundation for Climate and Atmospheric Sciences (CFCAS). The authors would like to thank Scott Jackson, Dave Lewis, Lynn Koehler, and Kelly Penrose for field assistance, and to Kara Pitman for processing a number of the samples. Earlier versions of this manuscript were improved with comments provided by Douglas Clark, Olav Lian and an anonymous reviewer. 


\section{References}

Barry, R.G. 2006. The status of research on glaciers and global glacier recession: A review. Progress in Physical Geography, 30: 285-306.

British Columbia Ministry of Environment. 2013. Ecoregion unit descriptions. Province of British Columbia. Available at: www.env.gov.bc.ca/ecology/ecoregions/humidtemp.html (accessed 30 March 2013).

Bronk Ramsey, C. and Lee, S. 2013 Recent and planned development of the program OxCal. Radiocarbon, 55: 720-730.

Chapin et al. 2014. Ch. 22: Alaska. In: Climate Change Impacts in the United States: The Third National Climate Assessment. Edited by J.M. Melillo et al. U.S. Global Change Research Program, 514.

Clague, J.J. and Mathewes, R.W. 1996. Neoglaciation, glacier-dammed lakes and vegetation change in northwestern British Columbia, Canada. Arctic and Alpine Research, 28: 10-24.

Clague, J.J. and Mathews, W.H. 1992. The sedimentary record and Neoglacial history of Tide Lake, northwestern British Columbia. Canadian Journal of Earth Sciences, 29: 2383-2396.

Cook, E.R. and Krusic, P.J. 2005. ARSTAN v. 41d: A tree-ring standardization program based on detrending and autoregressive time series modeling, with interactive graphics. Tree-Ring Laboratory, Lamont-Doherty Earth Observatory of Columbia University, Palisades, New York.

Coulthard, B.L. and Smith, D.J. 2013. Dendroglaciology. In: Elias S.A. (eds) The Encyclopedia of Quaternary Science. Amsterdam: Elsevier, vol. 2, pp. 104-111.

Desloges, J.R. and Ryder, J.M. 1990. Neoglacial history of the Coast Mountains near Bella Coola,British Columbia. Canadian Journal of Earth Sciences, 27: 281-290.

Dyurgerov, M.B. and McCabe, G.J. 2006. Associations between accelerated glacier mass and wastage increased summer temperature in coastal regions. Arctic, Antarctic, and Alpine Research, 38: 190-197.

Dyurgerov, M.B. and Meier, M.F. 2000. Twentieth century climate change: Evidence from small glaciers. Proceedings of the National Academy of Sciences of the United States of America, 97: 1406-1411. 
Environment Canada. 2014. Climate normals. National Climate Data and Information Archive. Available at: http://climate.weatheroffice.gc.ca/climate_normals/index_e.html (accessed 20 June 2014)

Gilbert, R., Desloges, J.R. and Clague, J.J. 1997. The glacilacustrine sedimentary environment of Bowser Lake in the northern Coast Mountains of British Columbia Canada. Journal of Paleolimnology, 17: 331-346.

Google Earth V 7.1.2.2041. 2014. Bowser River watershed, Canada, 56²6'35.73"N, $129^{\circ} 58^{\prime} 21.45^{\prime \prime W}$, eye alt 13.39km. Digital Globe 2014, http://www.earth.google.com, (accessed 21 Dec 2014).

Grissino-Mayer, H.D. 2001. Evaluating tree-ring accuracy: A manual and tutorial for the computer program COFECHA. Tree-Ring Research, 57: 205-221.

Hanson, G. 1932. Varved clays of Tide Lake, British Columbia. Transactions of the Royal Society of Canada, 26: 35-34.

Harvey, J.E., Smith, D.J., Laxton, S., Desloges, J. and Allen, S. 2012. Mid-Holocene glacier expansion between 7500 and 4000 cal. yr BP in the British Columbia Coast Mountains, Canada. The Holocene, 22: 975-985.

Haumann, D. 1960. Photogrammetric and glaciological studies of Salmon Glacier. Arctic, 13: 75-110.

Hoadley, R.B. 1990. Identifying Wood: Accurate Results with Simple Tools. Newton CT: The Taunton Press.

Hoffman, K.M. and Smith, D.J. 2013. Late Holocene glacial activity at Bromley Glacier, Cambria Icefield, northern British Columbia Coast Mountains, Canada. Canadian Journal of Earth Sciences, 50: 599-606.

Holm, K., Bovis, M., and Jakob, M. 2004. The landslide response of alpine basins to post-Little Ice Age glacial thinning and retreat in southwestern British Columbia. Geomorphology, 57: 201216.

Holmes, R.L., 1983. Computer assisted quality control in tree-ring dating and measurement. Tree-Ring Bulletin, 43: 69-78. 
Jackson, S.I., Laxton, S.C. and Smith, D.J. 2008. Dendroglaciological evidence for Holocene glacial advances in the Todd Icefield area, northern British Columbia Coast Mountains. Canadian Journal of Earth Sciences, 45: 83-98.

Johnson, K. and Smith, D.J. 2012. Dendroglaciological reconstruction of late-Holocene glacier activity at White and South Flat glaciers, Boundary Range, northern British Columbia Coast Mountains, Canada. The Holocene, 22: 987-995.

Kobashi, K., Severinghaus, J.P., Brook, E.J., Barnola, J.-M. and Grachev, A.M. 2007. Precise timing and characterization of abrupt climate change 8200 years ago from air trapped in polar air. Quaternary Science Review, 26: 1212-1222.

Larsen, C.F., Motyka, R.J., Arendt, A., Echelmeyer, K. and Geissler, P.E. 2007. Glacier changes in southeast Alaska and northwest British Columbia and contribution to sea level rise. Journal of Geophysical Research, 112: 1-11.

Le Roy, M., Astrade, L., Edouard, J-L., Miramont, C. and Deline, P. 2009. La dendroglaciologie ou l'apport de l'étude des cernes d'arbres pour la reconstitution des fluctuations glaciaires Holocènes. Neige et Glace de Montagne, Reconsitution, Dynamique, Practicques. Collection Edytem, 8: 79-90.

Menounos, B., Osborn, G., Clague, J.J. and Luckman, B.H. 2009. Latest Pleistocene and Holocene glacier fluctuations in western Canada. Quaternary Science Reviews, 28: 2049-2074.

Mood, B.J. and Smith, D.J. 2015. Holocene glacier activity in the British Columbia Coast Mountains, Canada. Quaternary Science Review, 128: 14-26.

Osborn, G., Haspel, R. and Spooner, I. 2013. Late-Holocene fluctuations of the Bear River Glacier, northern Coast Ranges of British Columbia, Canada. The Holocene, 23: 330-338.

Reimer, P.J., Bard, E., Bayliss, A., Beck, J.W., Blackwell, P.G., Bronk Ramsey, C., Buck, C.E., Cheng, H., Edwards, R.L., Friedrich, R.L., Grootes, P.M., Guilderson, T.P., Haflidason, H., Hajdas, I., Hatté, C., Heaton, T.J., Hoffman, D.L., Hogg, AB., Hughen, K.A., Kaiser, K.F., Kromer, B., Manning, S.W., Niu, M., Reimer, R.W., Rinchards, D.A., Scott, E.M., Southon, J.R., Staff, R.A., Turney, C.S.M. and van der Plicht, J. 2013. IntCal13 and marine 13 radiocarbon age calibration curves 0-50,000 years cal BP. Radiocarbon, 51: 1869-1887.

Reyes, A.V., Wiles, G.C., Smith, D.J., Barclay, D.J., Allen, S., Jackson, S., Larocque, S., Laxton, S., Lewis, D., Calkin, P.E. and Clague, J.J. 2006. Expansion of alpine glaciers in Pacific North America in the first millennium A.D. Geology, 34: 57-60. 
Ryder, J.M. and Thomson, B. 1986. Neoglaciation in the southern Coast Mountains of British Columbia: Chromology prior to the late Neoglacial maximum. Canadian Journal of Earth Sciences, 23: 273-287.

Schiefer, E., Menounos, B. and Wheate, R. 2008. An inventory and morphometric analysis of British Columbia glaciers, Canada. Journal of Glaciology, 54: 551-560.

Solomina, O.N., Bradley, R.S., Hodgson, D.A., Ivy-Ochs, S., Jomelli, V., Mackintosh, A.N., Nesje, A., Owen, L.A., Wanner, H., Wiles, G.C. and Young, N.E. 2015. Holocene Glacier Fluctuations. Quaternary Science Reviews, 111: 9-34.

Solomina, O.N., Bradley, R.S., Jomelli, V., Geirsdottir, A., Kaufman, D.S., Koch, J., McKay, N.P., Masiokas, M., Miller, G., Nesje, A., Nicolussi, K., Owen, L.A., Putnam, A.E., Wanner, H., Wiles, G. and Yang, B. 2016. Glacier fluctuations during the past 2000 years. Quaternary Science Reviews, 149: 61-90.

Stahl, K. and Moore, R.D. 2006. Influence of watershed glacier coverage on summer streamflow in British Columbia, Canada. Water Resources Research, 42: 1-5.

St-Hilaire, V.M. 2014. Holocene glacial history of the Bowser River watershed, northern Coast Mountains, British Columbia. MSc thesis. University of Victoria, Victoria.

Stokes, M.A. and Smiley, T.L. 1968. An Introduction to Tree-Ring Dating. Chicago, IL: The University of Chicago Press.

Walker, M. 2005. Quaternary Dating Methods. West Sussex: John Wiley and Sons Ltd.

Winkler, S. and Matthews, J. 2010. Holocene glacier chronologies: Are "high-resolution" global and inter-hemispheric comparisons possible? The Holocene, 20: 1137-1147. 


\section{List of Tables}

Table 1. Historical terminal retreat rates at Frank Mackie Glacier.

Table 2. Summary of radiocarbon dated samples at Frank Mackie Glacier.

Table 3. Subfossil chronologies established at Frank Mackie Glacier. 
Table 1. Historical terminal retreat rates at Frank Mackie Glacier.

\begin{tabular}{lllll}
\hline Period & $\begin{array}{l}\text { Retreat during } \\
\text { period }(\mathrm{m})\end{array}$ & $\begin{array}{l}\text { Mean rate of } \\
\text { retreat }(\mathrm{m} / \mathrm{yr})\end{array}$ & $\begin{array}{l}\text { Imagery Type, } \\
\text { Year }\end{array}$ & Source \\
\hline $1905-1972$ & 50 & $<1$ & $\begin{array}{l}\text { Photograph, 1905 } \\
\text { Aerial photo, }\end{array}$ & $\begin{array}{l}\text { 1BC6653 (Clague and } \\
\text { Matthews 1996) }\end{array}$ \\
$1972-1997$ & 150 & 6 & $\begin{array}{l}1972 \\
\text { Satellite image, } \\
2009\end{array}$ & Google Earth, Spot \\
$1997-2009$ & $342-700$ & $29-58$ & $\begin{array}{l}\text { Satellite image, } \\
2013\end{array}$ & $\begin{array}{l}\text { Microsoft Corporation, } \\
\text { Bing Maps }\end{array}$ \\
\hline
\end{tabular}


Table 2. Summary of radiocarbon dated samples at Frank Mackie Glacier.

\begin{tabular}{|c|c|c|c|c|c|c|}
\hline Lab No. & Sample ID & $\begin{array}{l}{ }^{14} \mathrm{C} \text { age } \\
(\mathrm{yr} \mathrm{BP})\end{array}$ & $\begin{array}{c}2 \sigma \text { calibrated } \\
\text { age }(\text { cal. yr BP })^{a}\end{array}$ & Location & $\begin{array}{c}\text { Elev. } \\
(\mathrm{m} \\
\text { asl) }\end{array}$ & Sample Description \\
\hline Beta-217006 & FM05-23 & $2380 \pm 40$ & $2690-2330$ & Site 5 , north moraine wall & 757 & $\begin{array}{l}\text { Oriented with direction } \\
\text { of glacier flow. }\end{array}$ \\
\hline Beta-217007 & FM05-24 & $2490 \pm 40$ & $2740-2380$ & Site 5 , north moraine wall & 755 & $\begin{array}{l}\text { In-situ, on organic } \\
\text { mat. }\end{array}$ \\
\hline Beta-242990 & FM05-0103 & $1760 \pm 40$ & $1810-1570$ & Site 1 , gully wall & 700 & In-situ in WL1 \\
\hline Beta-242991 & FM05-0104 & $870 \pm 40$ & $910-700$ & Site 1 , bowl shaped gully, & 705 & In-situ, upright \\
\hline Beta-242992 & FM05-0110 & $860 \pm 40$ & $900-690$ & $\begin{array}{l}\text { Site } 1 \text {, hanging at top } \\
\text { corner of gully wall/bowl }\end{array}$ & 715 & In-situ in WL2 \\
\hline Beta-242994 & FM05-0106 & $560 \pm 50$ & $650-510$ & Site 1 , bowl shaped gully & 720 & In-situ in WL3 \\
\hline
\end{tabular}

${ }^{a}$ Ages have been calibrated using OxCal 4.2 (Bronk Ramsey and Lee 2013) and the IntCal13 curve (Reimer et al., 2013). 
Table 3. Subfossil chronologies established at Frank Mackie Glacier.

\begin{tabular}{|c|c|c|c|c|c|c|}
\hline Sample ID ${ }^{a}$ & Site & $\begin{array}{l}\text { Maxim } \\
\text { um No. } \\
\text { rings }\end{array}$ & $\begin{array}{c}\text { Correlation } \\
\text { with master } \\
\text { chronology, } \\
\mathrm{r}\end{array}$ & $\begin{array}{l}\text { Perimeter } \\
\text { age }^{b} \\
\text { (cal. yr BP) }\end{array}$ & $\begin{array}{c}\text { Elevation } \\
\text { (m asl) }\end{array}$ & Location description \\
\hline
\end{tabular}

Cross-dated to $14 \mathrm{C}$ anchored floating tree-ring chronologies

Chron. A

\begin{tabular}{|c|c|c|c|c|c|c|}
\hline FM05-26 & 6 & 151 & 0.514 & 3227 & $670-685$ & detritus in incised gully \\
\hline FM05-27 & 6 & 178 & 0.409 & 3239 & $670-685$ & detritus in incised gully \\
\hline FM05-28 & $\begin{array}{c}6 \\
\text { Charlie }\end{array}$ & 70 & 0.451 & 3371 & $670-685$ & $\begin{array}{l}\text { detritus in incised gully } \\
\text { upright } 1.3 \mathrm{~m} \text { bole pressed between till }\end{array}$ \\
\hline KG13-01 & $\begin{array}{c}\text { Gl } \\
\text { Charlie }\end{array}$ & 59 & 0.523 & 3490 & 1080 & and bedrock \\
\hline KG13-29 & $\begin{array}{c}\text { Gl } \\
\text { Canoe }\end{array}$ & 140 & 0.443 & 3406 & 989 & buried perpendicular in gully \\
\hline CAN06-02 & $\begin{array}{c}\text { Gl } \\
\text { Canoe }\end{array}$ & 165 & 0.531 & 3358 & & in-situ in wood mat horizon \\
\hline CAN06-16 & Gl & 65 & 0.493 & 3355 & & detrial in wood mat horizon \\
\hline \multicolumn{7}{|l|}{ Chron. B } \\
\hline FM05-23 & 5 & 66 & 0.46 & 2521 & 757 & on organic wood mat \\
\hline FM05-24 & 5 & 87 & 0.46 & 2421 & 755 & on organic wood mat \\
\hline $\begin{array}{l}\text { FM05- } \\
\text { NSfc08 }\end{array}$ & 6 & 107 & 0.517 & 2394 & $670-685$ & detritus in incised gully \\
\hline $\begin{array}{l}\text { FM05- } \\
\text { NSfc17 }\end{array}$ & 6 & 191 & 0.494 & 2430 & $670-685$ & detritus in incised gully \\
\hline $\begin{array}{l}\text { FM05- } \\
\text { NSfc18 }\end{array}$ & 6 & 121 & 0.463 & 2482 & $670-685$ & detritus in incised gully \\
\hline $\begin{array}{l}\text { FM05- } \\
\text { NSfc19 }\end{array}$ & 6 & 175 & 0.53 & 2458 & $670-685$ & incised gully in north lateral moraine \\
\hline $\begin{array}{l}\text { FM05- } \\
\text { NSfc25 }\end{array}$ & 6 & 129 & 0.451 & 2495 & $670-685$ & detritus in incised gully \\
\hline
\end{tabular}

Chron. C

\begin{tabular}{|c|c|c|c|c|c|c|}
\hline FM05-0103 & 1 & 276 & 0.492 & 1675 & 700 & $\begin{array}{l}\text { in black organic layer, WL1 } \\
\text { standing upright in bowl gully above }\end{array}$ \\
\hline FM05-0105 & 1 & 112 & 0.597 & 1777 & 705 & WL1 \\
\hline FM05-L & 3 & 168 & 0.488 & 1680 & $580-680$ & detritus in moraine complex \\
\hline FM05-Z & $\begin{array}{c}3 \\
\text { Charlie }\end{array}$ & 113 & 0.455 & 1673 & $580-680$ & detritus in moraine complex \\
\hline KG13-06 & Gl & 100 & 0.443 & 1841 & 1080 & detrital wood in moraine colluvium \\
\hline \multicolumn{7}{|l|}{ Chron. D } \\
\hline FM05-0104 & 1 & 187 & 0.404 & 805 & 705 & standing upright in line with WL2 \\
\hline FM05-01 & 2 & 76 & 0.618 & 655 & 817 & in-situ in till of upper gully \\
\hline FM05-02 & 2 & 103 & 0.482 & 853 & 815 & in-situ in till of upper gully \\
\hline FM05-11 & 2 & 135 & 0.57 & 612 & 810 & detritus in red clay, WL4 \\
\hline
\end{tabular}




$\begin{array}{ccccccc}\text { FM05-12 } & 2 & 180 & 0.531 & 652 & 816 & \text { in-situ in red clay, WL4 } \\ \text { FM05-13 } & 2 & 78 & 0.467 & 750 & 808 & \text { detritus in massive till } \\ \text { FM05-14 } & 2 & 101 & 0.504 & 642 & 807 & \text { in-situ in red clay, WL4 } \\ \text { FM05-C } & 3 & 145 & 0.464 & 784 & 580-680 & \text { detritus in moraine complex } \\ \text { FM05- } & & & & & \\ \text { NSfc01 } & 6 & 250 & 0.415 & 707 & 670-685 & \text { detritus in incised gully } \\ \text { FM05- } & & 121 & 0.526 & 802 & 670-685 & \text { detritus in incised gully } \\ \text { NSfc02 } & 6 & & & & \\ \text { FM05- } & & 163 & 0.429 & 713 & 670-685 & \text { detritus in incised gully } \\ \text { NSfc05 } & 6 & & & & \end{array}$

Cross-dated to $14 \mathrm{C}$ living tree-ring chronologies

Chron. E

$\begin{array}{lcccccc}\text { FM05-09 } & 2 & 99 & 0.478 & 223 & 818 & \text { in-situ in red clay, WL4 } \\ \text { FM05-A } & 3 & 106 & 0.475 & 156 & 580-680 & \text { detritus in moraine complex } \\ \text { FM05-B } & 3 & 127 & 0.404 & 177 & 580-680 & \text { detritus in moraine complex } \\ \text { FM05-F } & 3 & 139 & 0.652 & 123 & 580-680 & \text { detritus in moraine complex } \\ \text { FM05-I } & 3 & 178 & 0.463 & 121 & 580-680 & \text { detritus in moraine complex } \\ \text { FM05-J } & 3 & 72 & 0.388 & 147 & 580-680 & \text { detritus in moraine complex } \\ \begin{array}{l}\text { FM05- } \\ \text { NSfc10 }\end{array} & 6 & 143 & 0.494 & 132 & 670-685 & \text { detritus in incised gully } \\ \begin{array}{l}\text { FM05- } \\ \text { NSfc23 }\end{array} & 6 & 144 & 0.382 & 141 & 670-685 & \text { detritus in incised gully }\end{array}$

Chron. F

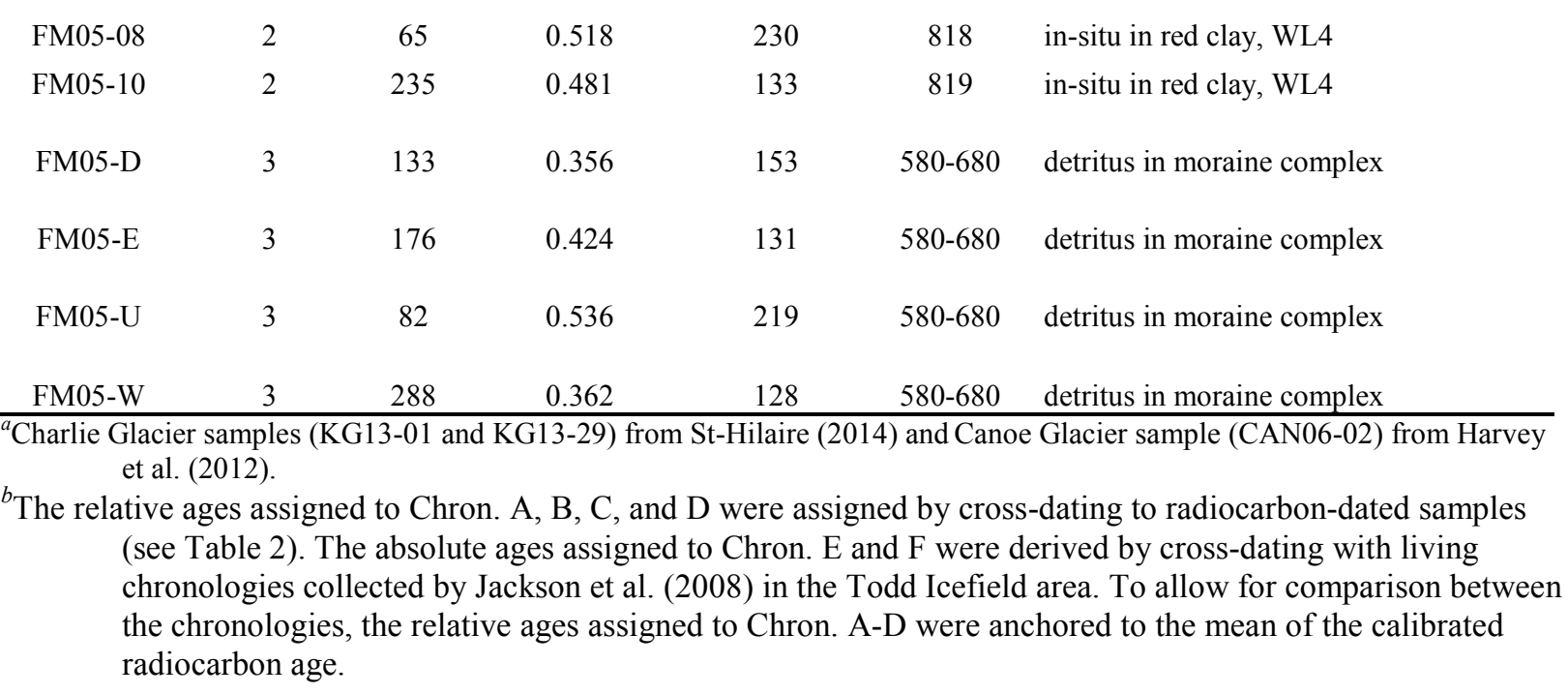




\section{List of Figures.}

Fig. 1. Location map of Frank Mackie Glacier within the Bowser River watershed, northern Coast Mountains, B.C. (Modified from Google Earth, 2013).

Fig. 2. Terminus area of Frank Mackie Glacier calving into Toe Lake, July 2013. View is looking up the Bowser River valley showing the location of Tide Lake until ca. 1930. In the middle background above the glacier are the recently exposed proximal lateral moraine slopes where Sites 1 and 3 are located.

Fig. 3. Oblique photograph of Frank Mackie Glacier showing location of sampling sites (July, 2013). Site 1- lower southern moraine; Site 2- upper southern moraine; Site 3- southern moraine complex; Site 4- forest; Site 5- northern lateral moraine; Site 6- spill area from northern lateral moraine

Fig. 4. Steep proximal face of Site 1, lower southern lateral moraine. Positions of prominent wood layers (WL1: $1760 \pm 40{ }^{14} \mathrm{C}$ years BP; WL2: $860 \pm 40{ }^{14} \mathrm{C}$ years BP; WL3: $560 \pm$ $50{ }^{14} \mathrm{C}$ years BP) indicated. In the middle backgound is the Bowser River valley with eroded and vegetated Tide Lake sediments pictured on the valley floor.

Fig. 5. Cross-section of Frank Mackie southern lateral moraines depicting relationship between sites 1-3.

Fig. 6. Stratigraphic section of major sedimentary units and position of wood layers at Site 1.

Fig. 7. Gully eroded into lateral moraine sediments at Site 2. Shown is the remains an rooted insitu tree trunk cross-dating to $200 \mathrm{cal}$. years BP, in an exposed portion of a wood layer, WL4.

Fig. 8. Frank Mackie northern lateral moraine, Site 5. Shown is the position of wood layer, WL5, located at the boundary between two diamict units dating to $2490-2380 \pm 40{ }^{14} \mathrm{C}$ years BP (FM05-23, -24).

Fig. 9. Summary subfossil tree chronologies constructed from Frank Mackie Glacier sites.

Footnotes:

${ }^{a}$ Cross-dated samples are grouped with brackets. Each rectangle represents the temporal extent of a sample. Error bars for chronologies A-D represent two standard deviation margin associated with the radiocarbon-dated samples. Chronologies $\mathrm{E}$ and $\mathrm{F}$ are cross-dated with living tree chronologies.

${ }^{b}$ Charlie Glacier samples (KG13-01, KG13-06 and KG13-29) from St-Hilaire (2014)

${ }^{c}$ Canoe Glacier sample (CAN06-02) from Harvey et al. (2012).

Fig. 10. Summary of radiocarbon ages from Frank Mackie Glacier (this study), Tide Lake (Clague and Mathews 1992), Canoe Glacier (Harvey et al. 2012) and the Todd Valley 
Glaciers (Jackson et al., 2008). Plot outputs and radiocarbon calibration from OxCal v4.2.3 (Bronk Ramsey and Lee 2013); r:5 IntCal13 atmospheric curve (Reimer et al. 2013). 


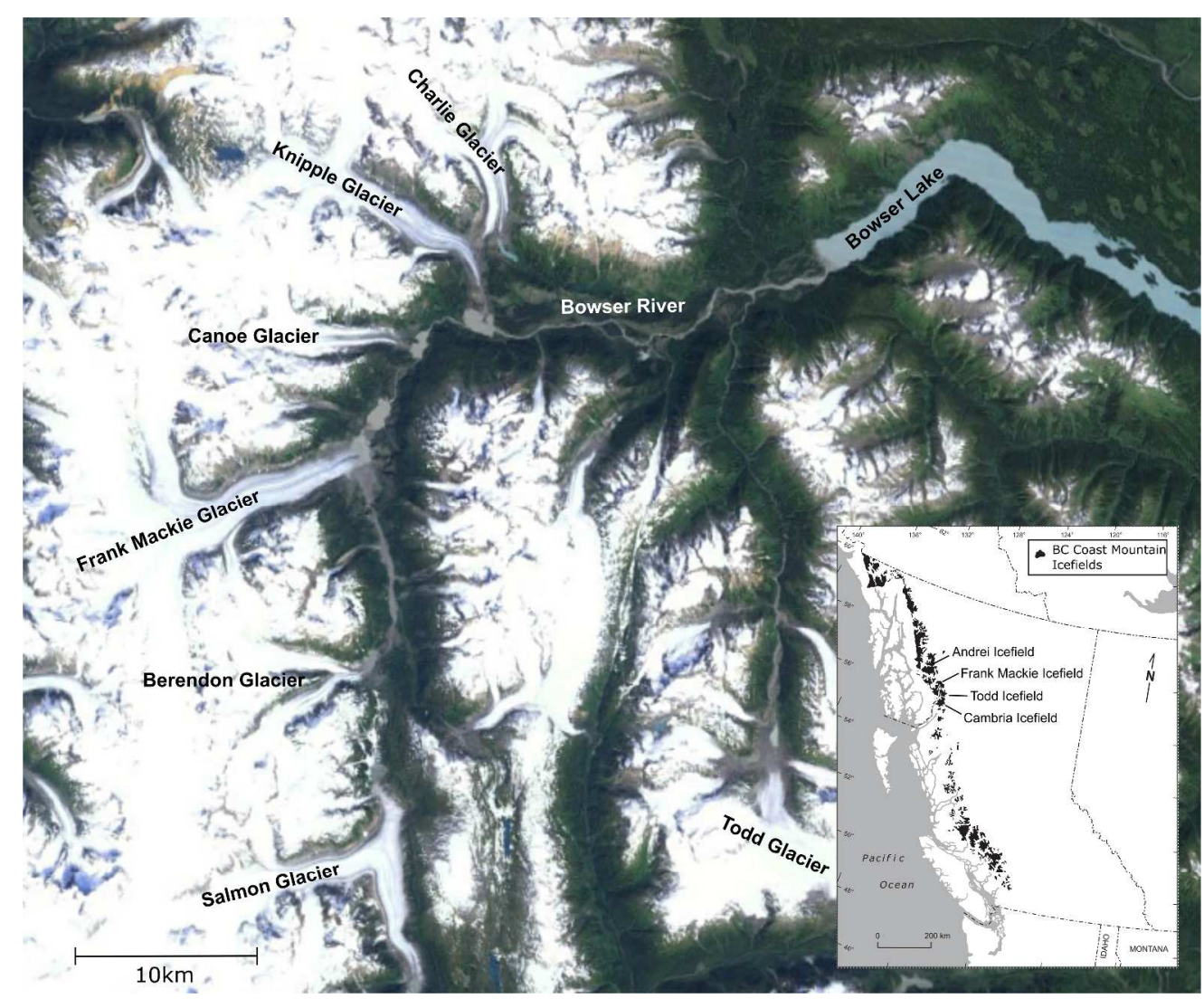

Fig. 1 


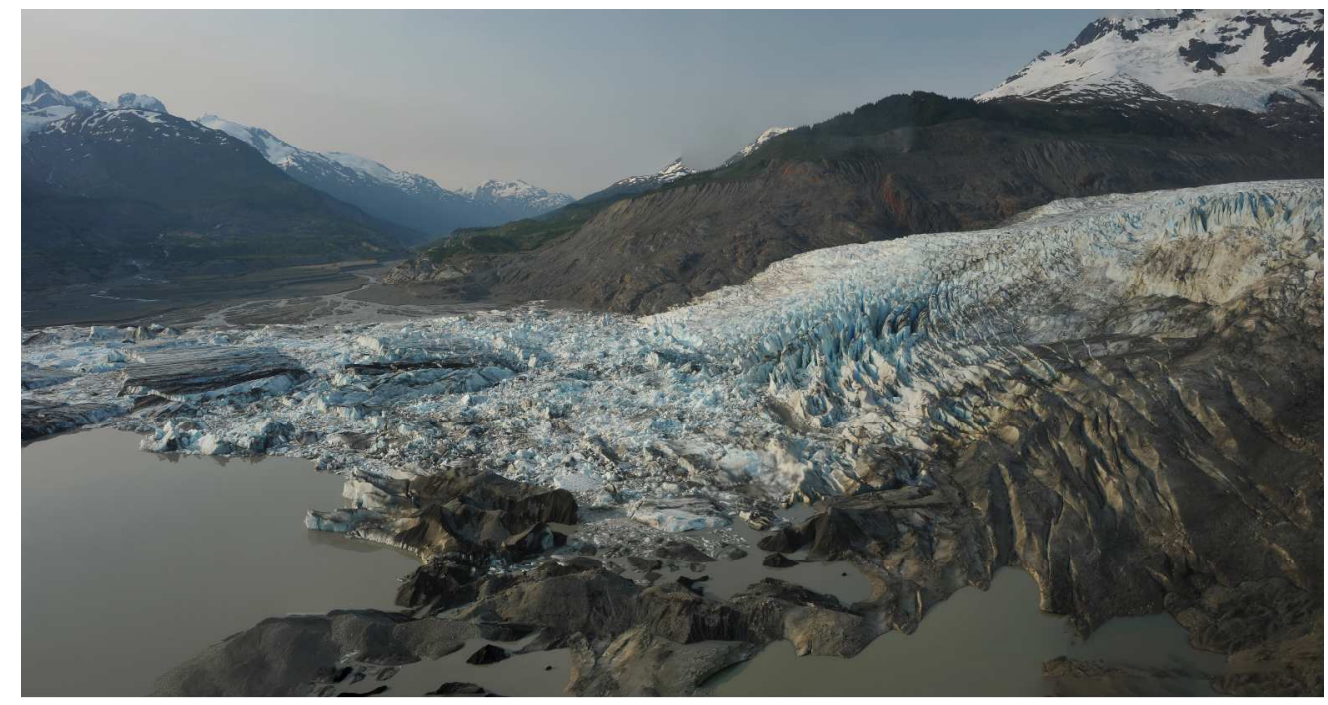

Fig. 2.

$490 \times 259 \mathrm{~mm}(300 \times 300$ DPI $)$ 


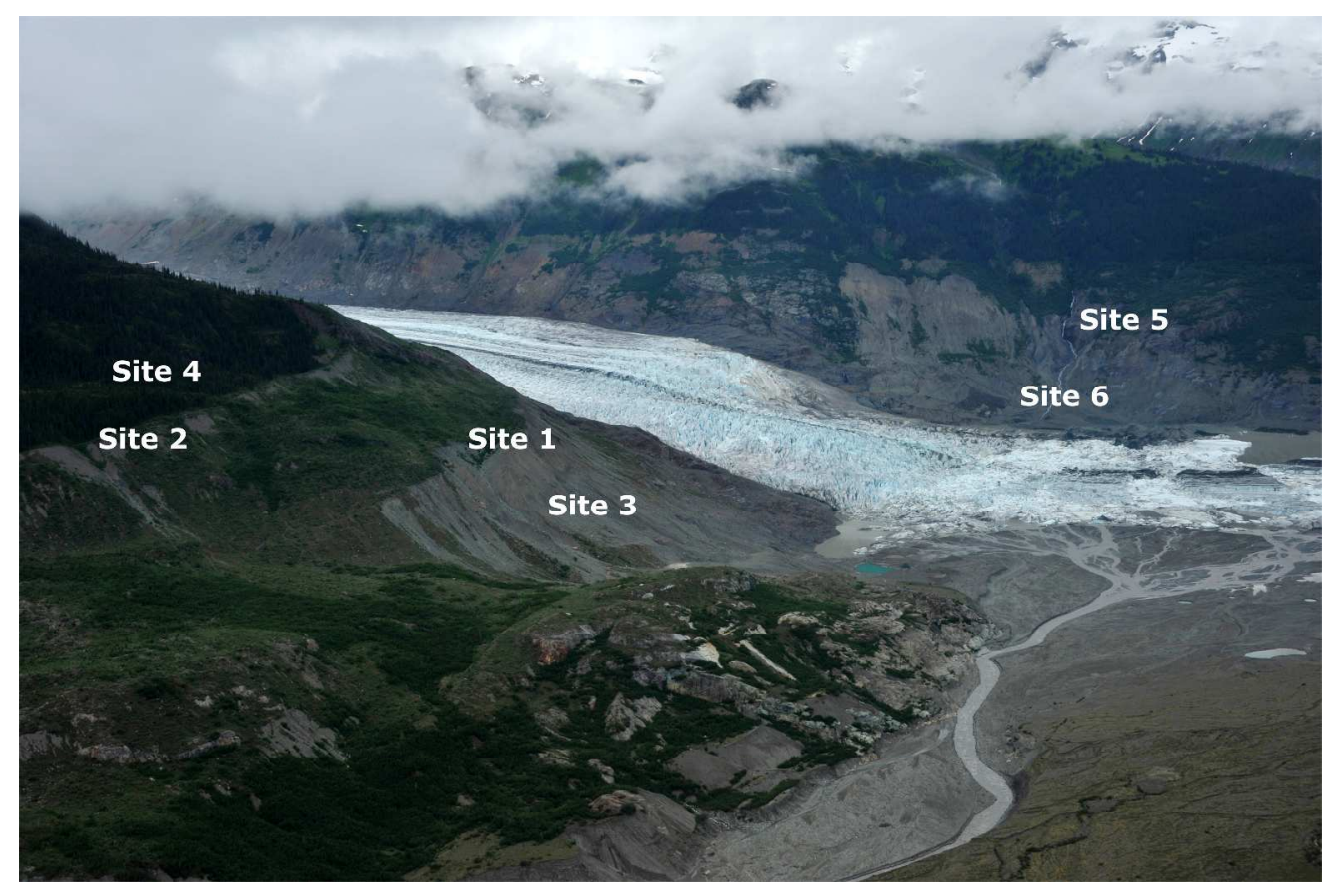

Fig. 3. 


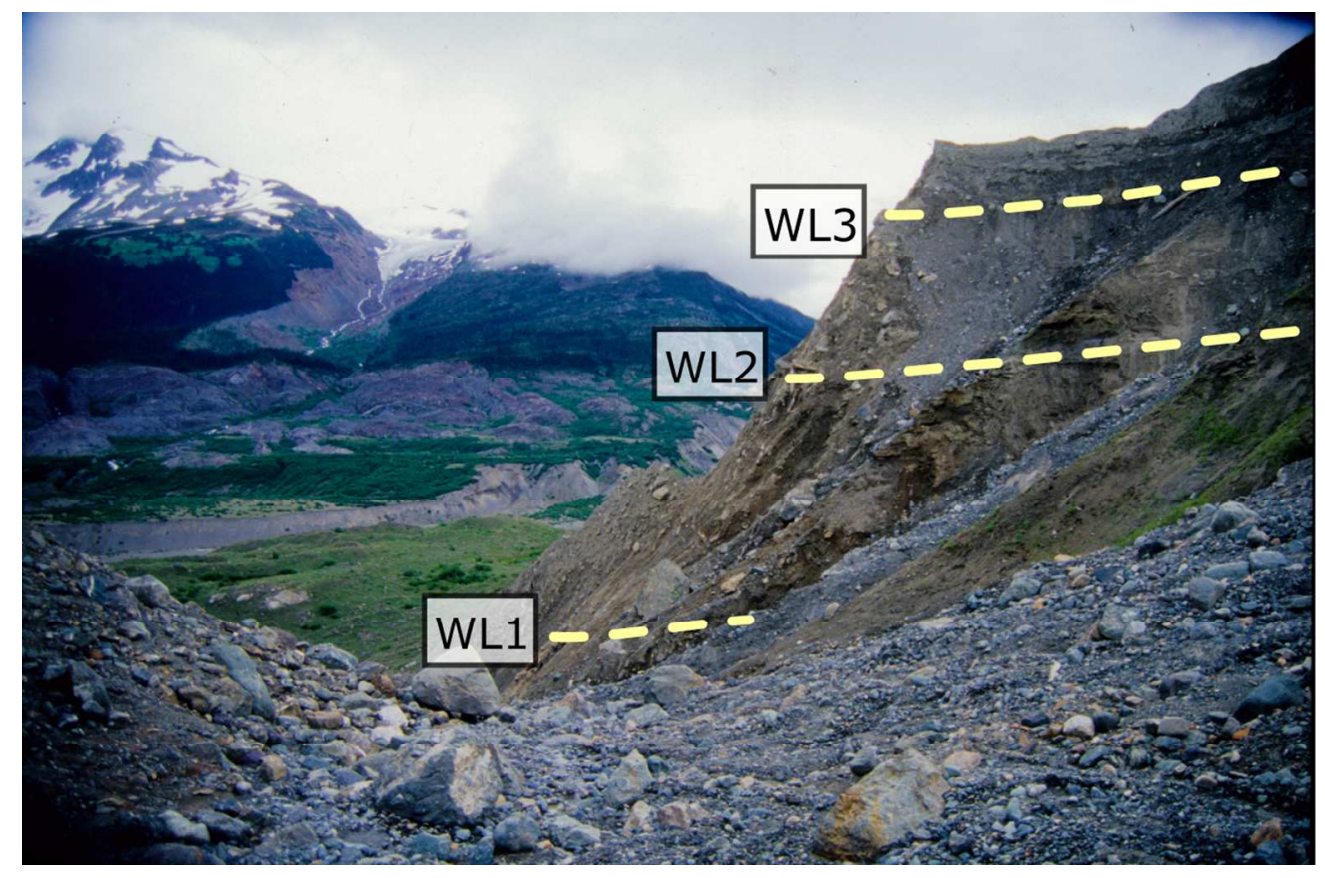

Fig. 4. 


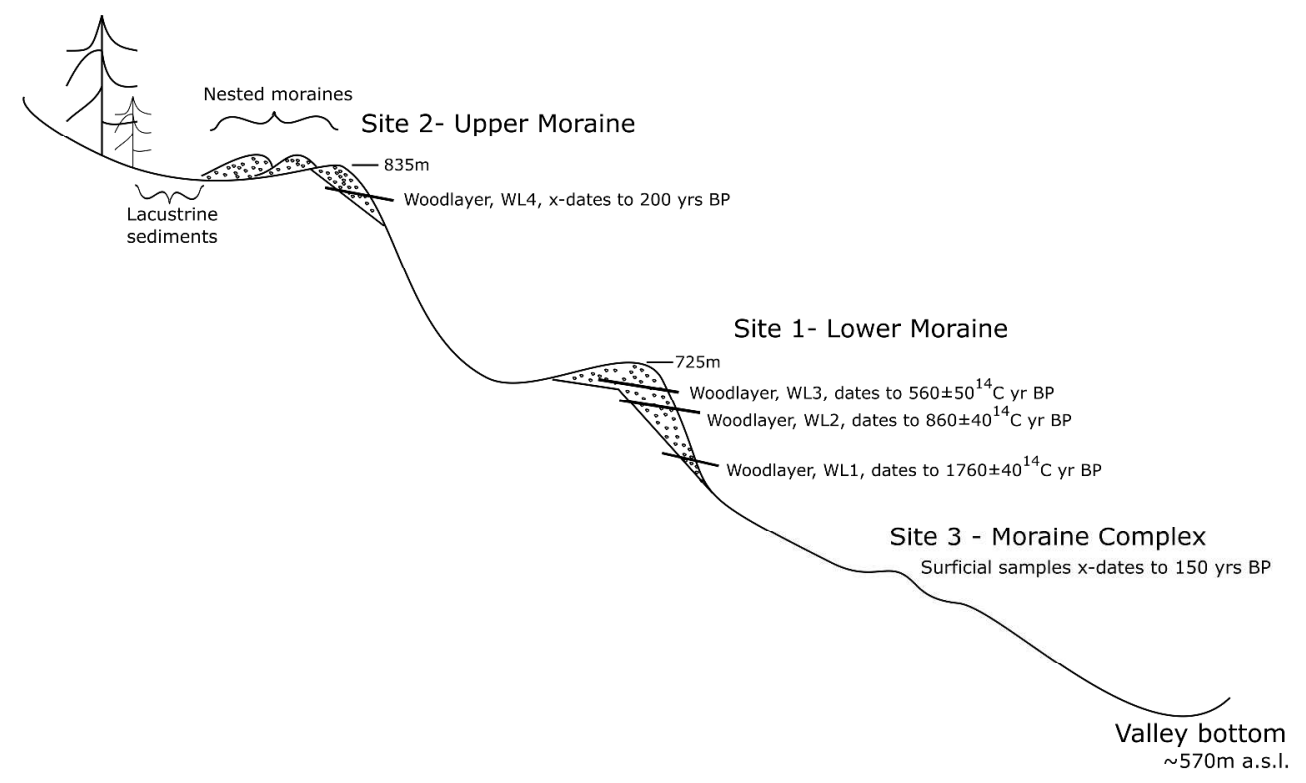

Fig. 5. 


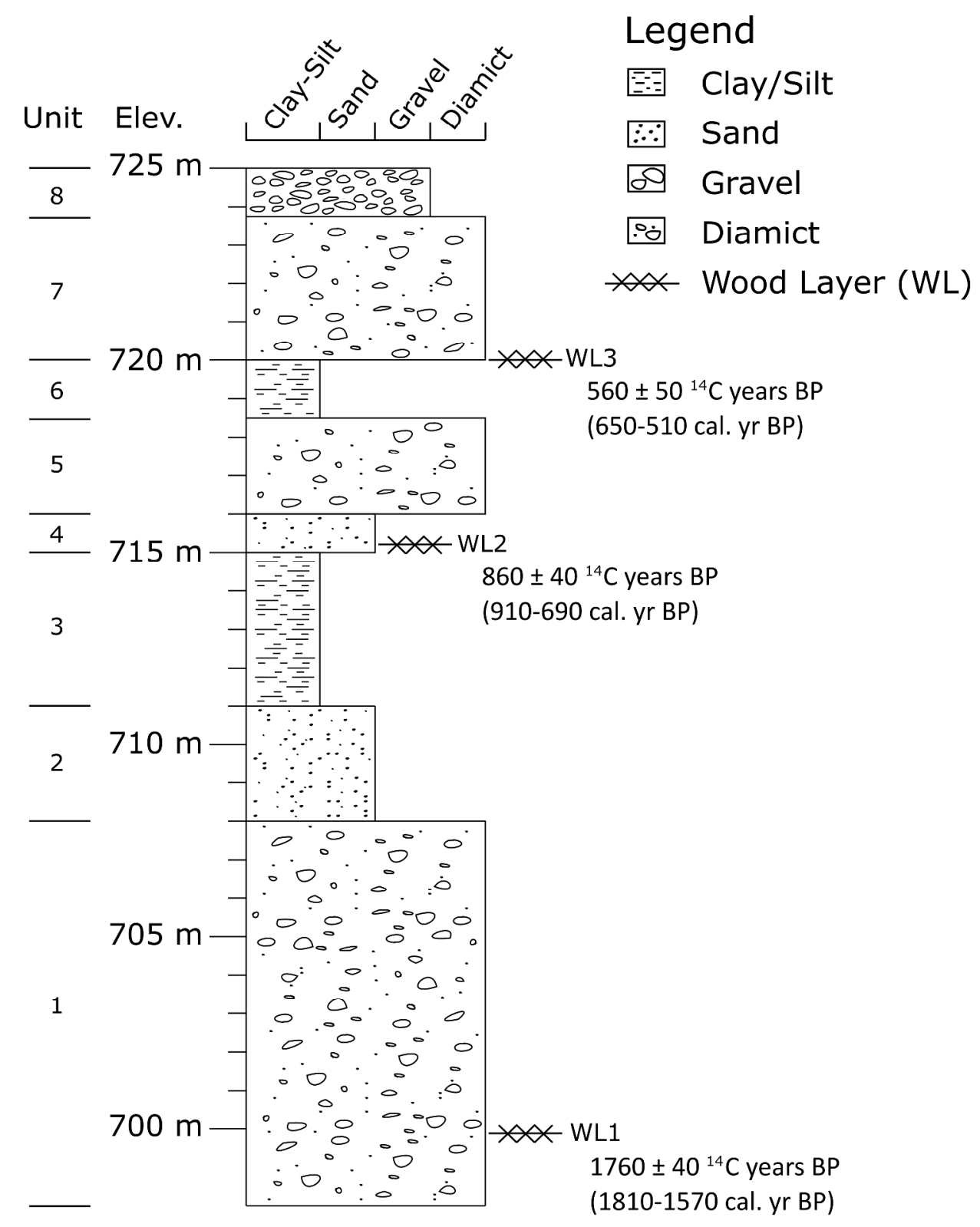

Fig. 6. 


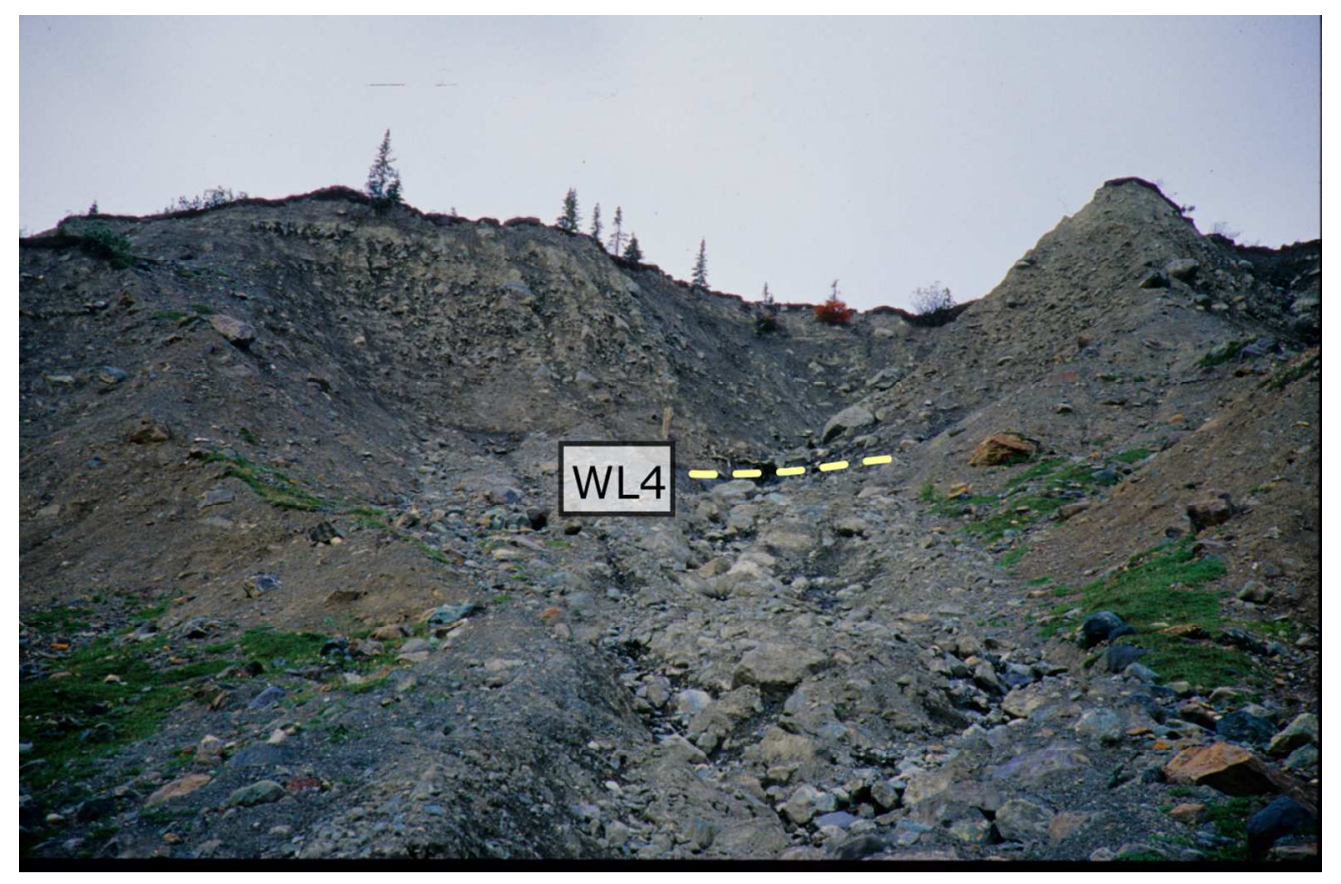

Fig. 7. 


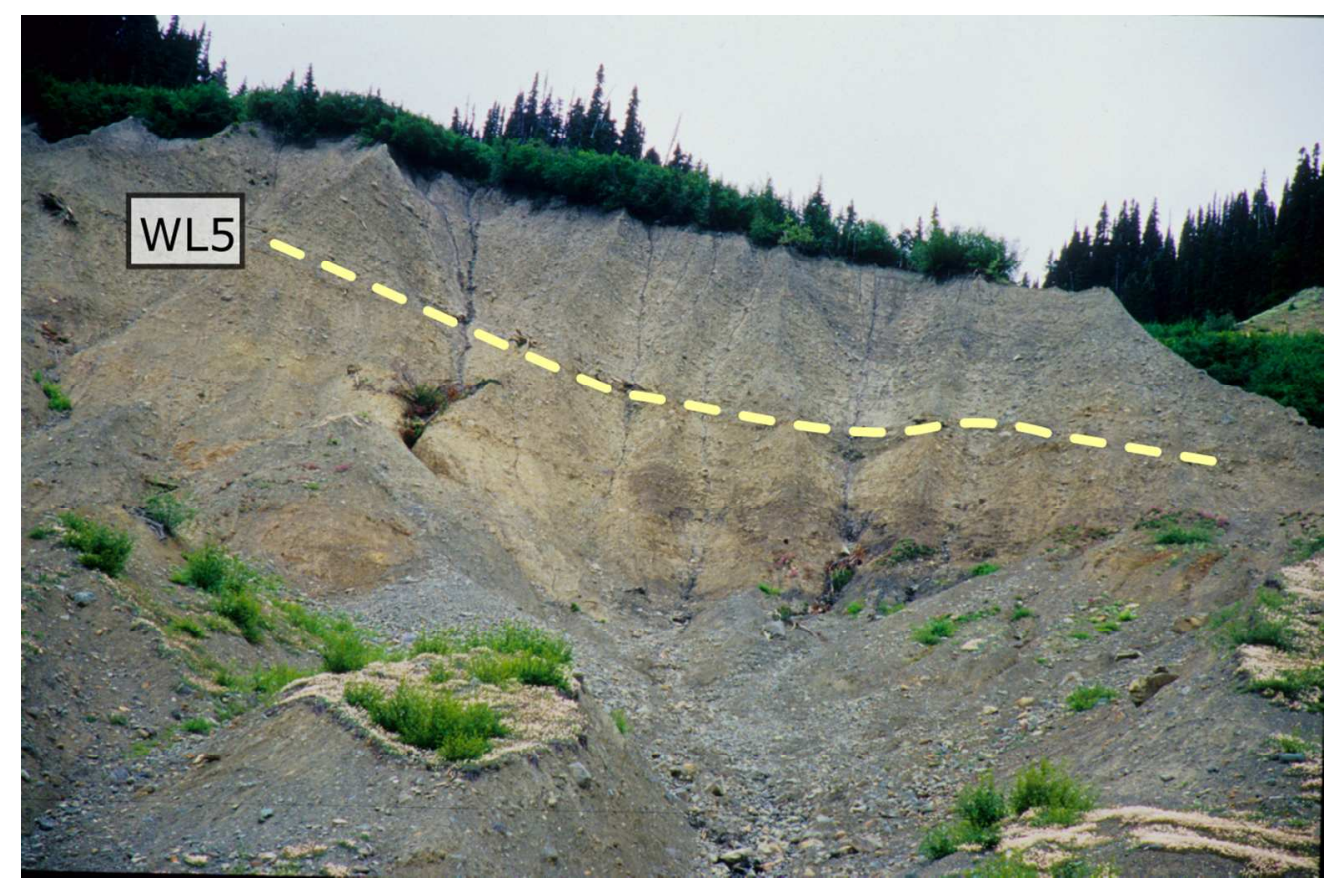

Fig. 8 . 


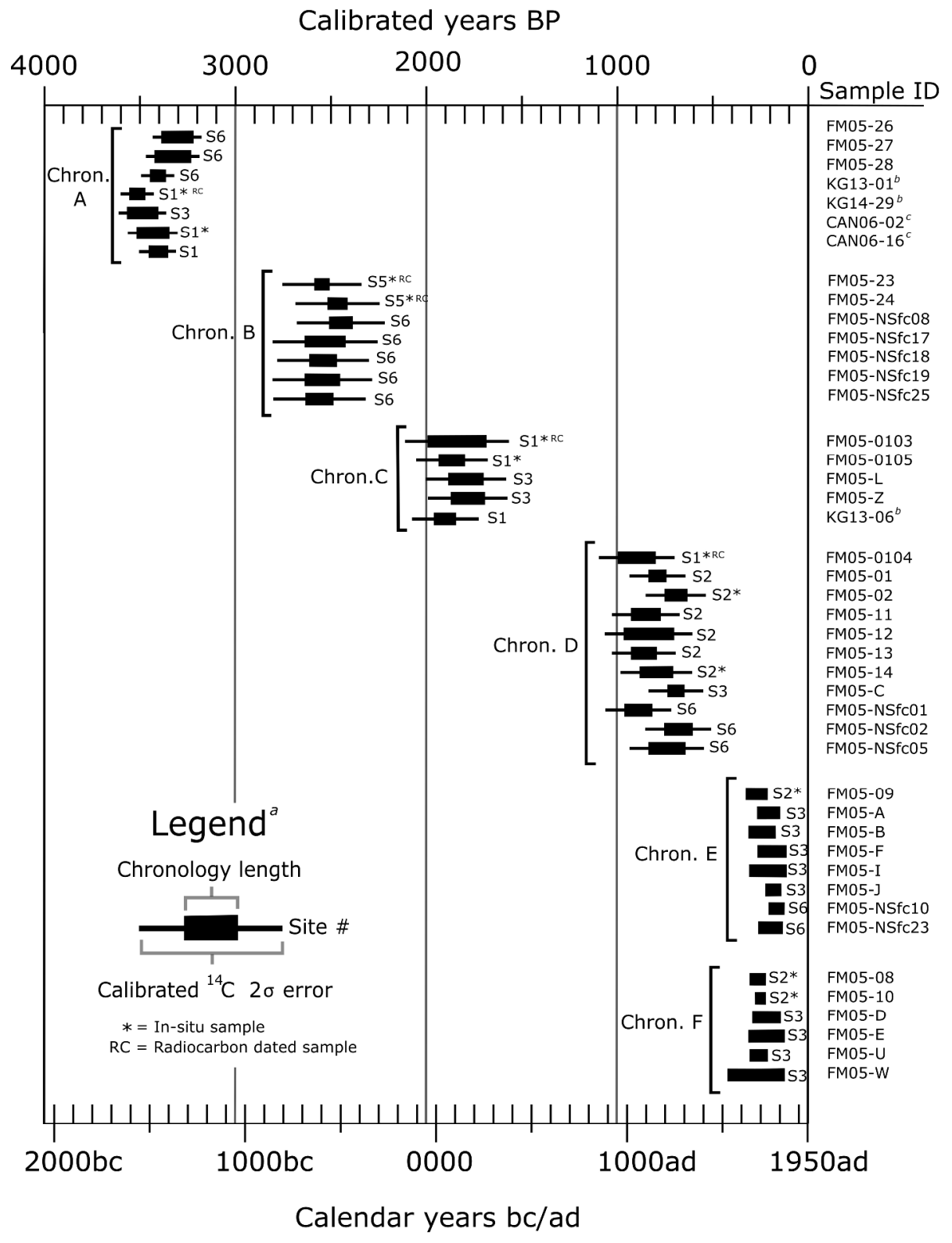

Fig. 9. 


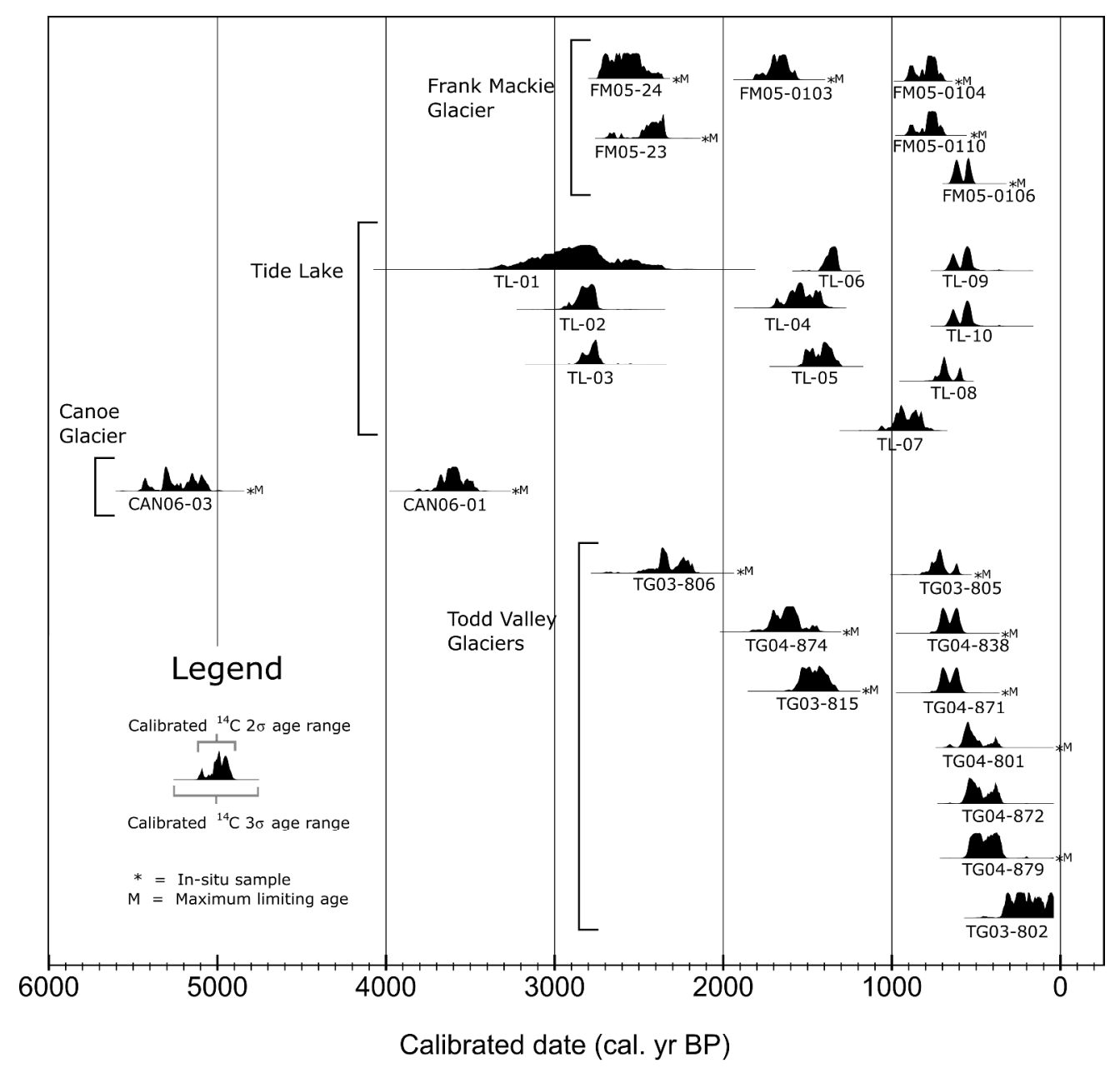

Fig. 10. 